\title{
Рослякова С.В.
}

\section{Учебно-познавательная состоятельность школьника как фактор его успешности в настоящем и будущем}

\author{
Roslyakova S.V. \\ Educational and cognitive consistency student as a factor \\ of its success in the present and future
}

В данной статье на основе изучения сущности понятия «состоятельность» 8 общеупотребительном и научном смыслах осуществлена попытка его в педагогике: отмечены его ключевые характеристики, определено его содержание, выражено авторское представление о состоятельности в учебнопознавательной деятельности

Ключевые слова: состоятельность, учебнопознавательная состоятельность, ресурсы личности, учебная и жизненная успешность

\section{Рослякова Светлана Васильевна}

Кандидат педагогических наук, доцент

Челябинский государственный педагогический университет

2. Челябинск, пр. Ленина, 69

\begin{abstract}
This article based on the study of essence of concept "consistency" in the common and scientific sense of the attempt of his pedagogy: marked its key characteristics which determined its content, expressed understanding of the author's consistency in teaching and learning activities
\end{abstract}

Key words: solvency, educational and cognitive consistency, personal resources, training and life success

\author{
Roslyakova Svetlana Vasilyevna \\ Candidate of Pedagogic Sciences, Associate Professor \\ Chelyabinsk state pedagogical university \\ Chelyabinsk, Lenina ave., 69
}

Современная система образования и школа как социальный институт являются ответственными не только за качество знаний обучающихся, но и за их успешность в будущей учебной и профессиональной деятельности, адекватное функционирование в различных жизненных ситуациях. Этим фактом определяет направленность в образовании на реализацию идеи формирования у обучающихся способности учиться на протяжении всей жизни. Именно в школьные годы у учеников должна быть сформирована способность и готовность приобретать знания, умения и навыки, компетенции, которые станут в будущем основой успешной учебной и познавательной деятельности.

В настоящее время более приемлемым понятием для определения способности и готовности человека осуществлять определенный вид деятельности считается понятие «компетентность». Однако наша жизнь и ориентация в ней на успешность и конкурентоспособность современного человека все чаще убеждают в потребности использования такого понятия, как состоятельность. 
Нас интересует, состоялся ли человек как личность, профессионал, семьянин и т.П.

Следует сказать, что основной сферой употребления понятия «состоятельность» является экономика и бизнес. Но в последние годы его стали заимствовать психология, медицина. В этой связи мы обнаружили потребность применения данного понятия и в педагогике. Считаем, что учащегося, оканчивающего школу, тоже можно оценивать на предмет его состоятельности в учебной деятельности, без которой его трудно представить студентом вуза или человеком, осуществляющим профессиональную деятельность, движущимся к намеченной цели, успеху, способным самореализоваться в жизни.

Слово «состоятельность» близко по значению словам «состояться», т.е. произойти, осуществиться; «состояние» - положение, в котором кто-нибудь или что-нибудь находится, а также имущество, собственность. Понятие «состоятельность» в толковых словарях Д.Н. Ушакова [5] и С.И. Ожегова [3] рассматривается как правило в двух значениях: применительно к процессу мышления - состоятельность рассуждения, его достоверность, доказательность, обоснованность, а во-вторых, для оценки степени материального благосостояния, платежеспособности человека: состоятельный, согласно словарю С.И. Ожегова, - это богатый, обеспеченный [3].

В экономике и бизнесе состоятельность рассматривают в качестве продукта, следствия, порождения философии потребления и культуры отношения человека к деньгам. Используются понятия «финансовая, экономическая состоятельность». Как экономический термин состоятельность характеризуется следующим образом: а) представляет собой систему знаний о накапливании капитала и управления им, а также состояние обеспеченности; б) имеет временную характеристику - измеряется в днях, месяцах, годах, которые человек может прожить, не работая, на привычном для себе уровне потребления; в) соотносится с понятием «богатство», но определяется не столько количественными характеристиками (суммой), сколько временными (на сколько хватит капитала при привычном уровне потребления).

В психологии понятие «состоятельность» встречается в работах Э. Берна [1], В.А. Петровского [4]. Со ссылкой на этих исследователей разрабатываются понятия «профессиональная состоятельность», «личностная состоятельность». Под личностной состоятельностью понимается многомерное образование, позволяющее оценивать состоятельность личности в ситуации выбора, на основании анализа определенных личностных устремлений и определенных возможностей их реализации (М.К. Худышева) [7].

Особенность подхода к понятию состоятельность в психологии заключается в следующих ее характеристиках: а) это мера реализуемости личностью жизненных (профессиональных) потребностей на основе имеющихся внутренних и внешних ресурсов; б) структура включает интенциональную (ценностномотивационную) и инструментальную образующие; в) является условием, обеспечивающим постоянное расширение возможностей человека для освоения новых видов труда и способов жизнедеятельности, как «выход человека за рамки самого себя» (В. Франкл); г) результатом является активная, субъектная 
жизненная позиция личности, умение самостоятельно определять цели и пути их достижения.

В области медицины Н.П. Ничипоренко, В.Д. Менделевич [2] определяют содержание понятия «антиципационная состоятельность» личности, указывая на близость понятий состоятельность и компетентность. Анализ работ данных исследователей показал, что антиципационная состоятельность помимо специфических характеристик имеет общее, что ее связывает с другими видами состоятельности: относится к категории устойчивых индивидуальнопсихологических свойств (или качеств) личности, формирующихся на основе задатков, определяет успешность в том или ином виде деятельности.

В период обучения в школе, по мнению психологов, происходит становление школьника прежде всего как субъекта учебной деятельности (В.В. Давыдов, А.Г. Асмолов и др.) [6]. К одиннадцатому классу школьник должен продемонстрировать свою компетентность во многих видах деятельности, но прежде всего учебно-познавательной. Совокупное умение ученика учиться, его способность осуществлять учебную деятельность говорит о состоятельности / несостоятельнсоти в учебно-познавательной деятельности.

Учитывая сущность понятия «состоятельность», раскрытую в работах психологического, медицинского, экономического направлений, попытаемся сформулировать представление о состоятельности как педагогическом феномене. Что значит состоятельность человека в учебно-познавательной деятельности? Это значит, что он состоялся в ней, т.е. «приобрел законченный вид», что говорит о завершенности, наличии результативной характеристики данного понятия. Состоятельный - значит богатый, обеспеченный, имеющий чтото в своем составе. В учебной деятельности богатство составляют умения учиться, являющиеся капиталом для всей последующей жизни, который невозможно растратить, он может только пополнятся.

Состоятельность в учебно-познавательной деятельности, если сослаться на точку зрения экономистов, можно рассматривать как количественнокачественную характеристику: это капитал, обеспеченность в прямом и переносном смысле, это «богатство», которое послужит человеку долгие годы. Но в отличие от временной экономической характеристики состоятельности личности в учебно-познавательной деятельности не грозит «растрата», с годами состоятельность, наоборот, может расти, увеличиваться.

Проанализировав представления исследователей о разных видах состоятельности, мы пришли к выводу, что состоятельность согласуется с такими понятиями, как «готовность», «компетентность», «способность», «самодостаточность» на всех уровнях организации жизни человека (духовном, финансовом, социальном и др.). Если говорить об учебно-познавательной состоятельности школьника, со ссылкой на проанализированные источники ее мы предлагаем рассматривать как:

- свойство личности, количественно-качественную устойчивую характеристику, определяющую уровень развития учебно-познавательных способностей (умения учиться); 
- готовность к осуществлению эффективной учебно-познавательной деятельности в отношении мира и самого себя;

- сформированную систему знаний в действии (компетенций), обеспечивающих эффективное познание и учение; т.е. учебно-познавательную компетентность;

- систему, прежде всего, внутренних средств построения и регуляции познавательной активности;

- определенное «состояние» и характеристику системы внутренних ресурсов личности (ценностно-ориентационных, когнитивных и деятельностных), обеспечивающих успешность познавательной деятельности.

Подводя итог сказанному, отметим, что обращение к понятию «состоятельность» обусловлено, прежде всего, ориентацией современного образования на успешность человека. Школьник, состоявшийся как субъект учебнопознавательной деятельности, как лицо компетентное в ней, безусловно, будет успешен и в учебе в вузе, будет способен адаптироваться к любым условиям и ситуациям, а главное - будет способен расти и самореализоваться в жизни, а значит, успешен и счастлив.

\section{Список используемых источников:}

1. Берн Э. Игры, в которые играют люди. Люди, которые играют в игры. М., 2006. 397 с.

2. Ничипоренко Н.П., Менделевич В.Д. Феномен антиципационных способностей как предмет психологического исследования // Психологический журнал. 2006. № 5. С. 50-58.

3. Ожегов С.И. Толковый словарь русского языка: ок. 100000 слов, терминов и фразеологических выражений. М., 2010. 736 с.

4. Петровский В.А. Личность в психологии: парадигма субъектности. Ростов-н/Д., 1996. 512 с.

5. Толковый словарь Ушакова. URL: http://ushakovdictionary.ru.

6. Асмолов А.Г. Формирование универсальных учебных действий в основной школе: от действия к мысли. М., 2011. 159 с.

7. Худышева М.К. Условия становления личностной состоятельности будущего профессионала. Автореферат диссертации. М., 2004. 28 с.

(C) 2015, Рослякова С.В.

Учебно-познавательная состоятельность школьника как фактор его успешности в настоящем и будущем
(C) 2015, Roslyakova S.V.

Educational and cognitive consistency student as a factor of its success in the present and future 